\title{
Hominid-Pongid Distinctiveness in the Miocene-Pliocene Fossil Record: The Lothagam Mandible
}

\author{
ANDREW KRAMER \\ Department of Anthropology, University of Michigan, Ann Arbor, \\ Michigan 48109
}

\author{
KEY WORDS Australopithecus afarensis, Hominid origins, Dental/ \\ gnathic evolution
}

\begin{abstract}
The Lothagam mandibular fragment, found in 1967 west of Lake Turkana, Kenya, has been dated to $\mathbf{5 . 5}$ million years ago. This date is significant because it may lie within the suggested time range during which the hominid and pongid clades diverged. Because of its fragmentary condition and great age, this specimen has run the gamut of taxonomic assignations, from ramapithecine to pongid to hominid. These three nomenclatural categories serve as the basis for three hypotheses tested in this study. First, morphological and metric comparisons between Lothagam and a sample of Euroafrican ramapithecines address the hypothesis of "Lothagam as predivergence hominoid." Second, comparisons with a sample of Pan test the "Lothagam as postdivergence, African protopongid" hypothesis. Finally, samples of Australopithecus afarensis and $A$. africanus were utilized to evaluate the hypothesis of "Lothagam as postdivergence, early hominid." Unlike previous studies attempting to ascertain the evolutionary affinities of this enigmatic fossil, this work benefits from the large sample of $A$. afarensis specimens now generally available for study. Metric and morphological comparisons demonstrate Lothagam's affinity to $A$. afarensis in sharing derived, hominid states in such features as the mental foramen vertical position, the ascending ramus origin, the breadth of the alveolar margin, the reduction of the hypoconulid, the dimensions of the $\mathbf{M}_{1}$ and the dimensions of the mandibular corpus. It is suggested that the dental/gnathic features enumerated in this study can be employed to distinguish ancestral hominid from pongid in future Mio/Pliocene paleontological discoveries.
\end{abstract}

One of the most irksome problems plaguing studies of hominid origins is the nearly complete dearth of hominoid fossils dating from the Late Miocene to the Early Pliocene. This time period, namely, from about 9 to 4 million years ago $(\mathrm{Ma})$, is extremely important because biochemical (Sarich, 1968, 1970; Sarich and Wilson, 1967; Sarich and Cronin, 1977; Washburn and Moore, 1974; King and Wilson, 1975; Cronin, 1983; Goodman et al., 1983; Sibley and Ahlquist, 1984) and paleontological (Washburn, 1950; Greenfield, 1980, 1983; Andrews, 1982; Feldesman, 1982; Kay and Simons, 1983; Gingerich, 1984; Pilbeam, 1985) studies have independently suggested that the split between the hominid and African pongid lineages may have occurred dur- ing this time. Unlike the abundant Middle to Late Pliocene $A$. afarensis material recovered from East Africa, which demonstrated the hallmark hominid attribute of bipedality, the scant fossil evidence from the earlier 9-4 Ma range is completely dental/ gnathic and consists of only two specimens adequately described in the literature. The first is the lower molar from Lukeino (KNMLN 335), central Kenya, which was brack. eted by potassium-argon dates of 7 and 5.4 Ma (Pickford, 1975). The second is the mandibular fragment from Lothagam (KNM-LT 329 ), northern Kenya, which has been varia-

Received February 25, 1985; revision accepted February 12 1986. 
bly suggested to be as old as $6 \mathrm{Ma}$ (Smart, 1976; Coppens, 1978), between 5.5 and $5 \mathrm{Ma}$ (Patterson et al., 1970; Behrensmeyer, 1976), and, most recently, has been radiometrically bracketed between 8.5 and $3.8 \mathrm{Ma}$ (Brown et al., 1985). Most researchers today agree upon an age range of 6-5 $\mathrm{Ma}$ for Lothagam.

The purpose of this work is to determine what, if any, dental/gnathic features can be employed to distinguish hominids from pongids near the point of these clades' evolutionary divergence and to apply these to the few fossils known from the time range in question. While the Lukeino specimen is simply a solitary molar, the Lothagam fossil consists of a partial right mandibular corpus with $\mathrm{M}_{1}$ intact, as well as the roots of $\mathrm{M}_{2}$, and it is therefore potentially more informative with respect to the goal of this study. As a result, the focus of this paper will be concentrated on the Lothagam mandible.

\section{HISTORY OF INTERPRETATION}

The chronological placement of Lothagam and its relatively fragmentary condition have contributed to its wide and varied array of taxonomic assignations. Found in 1967 by an expedition from Harvard University's Museum of Comparative Zoology at Lothagam Hill, southwest of Lake Turkana, Kenya, it was originally attributed to Australopithecus sp. cf. A. africanus (Patterson et al., 1970). While Tobias (1978) and Simons (1978) first echoed this viewpoint, the latter revised his position by declining to speculate on its specific affinity; rather, he simply stated that Lothagam "resembles early Australopithecus" (Simons, 1981, p. 22). Others have refused even to offer a generic label for this specimen, preferring instead Hominidae indet. These researchers include Howell (1978), who noted that Lothagam lacked the lateral toral and internal basilar thickening that characterized even the small australopithecines, and Szalay and Delson (1979), who felt that its fragmentary condition precluded a generic assessment. McHenry and Corruccini (1980) and Corruccini and McHenry (1980) also preferred Hominidae indet., because their metrical analyses using Penrose shape distances, Mahalonobis' D, canonical variates, and morphometric cladistics demonstrated Lothagam's intermediacy between A. afarensis and modern African pongids. Tanner shares the equivocal feelings of the above researchers, stating that "this fossil could represent either the ancestral ape line or be a remnant of the transitional population" (1981, p. 171). A still more cautious assignment to Hominoidea indet. is offered by White (1977a) as a result of the orientation of the mental foramen, the flattened lateral corpus contours, the horizontal extension of the ramus base, and the strong subalveolar hollowing in KNM-LT 329, all of which he regards as pongid-like features. White (1986), in a recent reappraisal of the Lothagam fossil, still maintains his original belief that the specimen is not diagnostic at lower than the superfamily level.

Finally, some researchers have concluded that the Lothagam mandible is not a representative of the human family. Eckhardt (1977) regarded Lothagam as being morphologically similar to the large dryopithecine palate from Moroto, Uganda, because the two specimens occluded. He also stated that "sixteen repeatable measurements" metrically align this specimen with "modern African pongids" (Eckhardt, 1977, p. 356). R.E.F. Leakey's analysis (1973) of the specimen led him to speculate that the Lothagam fossil was a representative of a late surviving species of Ramapithecus.

\section{MATERIALS AND METHODS}

Upon analysis, the Lothagam literature reveals three basic hypotheses concerning this enigmatic specimen's evolutionary position. The first, championed by Leakey (1973) and to a lesser degree by Eckhardt (1977), contends that KNM-LT 329 is representative of a predivergent stock of ancestral hominoids or perhaps is a member of a relict sidebranch of hominoids that left no descendants. The second, propounded for the most part by Eckhardt (1977), suggests that Lothagam is a member of the postdivergent African ape clade. The third hypothesis, which is by far the most popular among those who have studied the specimen, states that Lothagam represents the earliest of the Hominidae.

Testing the first hypothesis required an analysis of the group of hominoids generally believed to be ancestral to both the hominids and the pongids. The Middle to Late Miocene ramapithecines of Africa were most likely to include these ancestors (Pilbeam, 1979, 1985; Greenfield, 1980; Lipson and Pilbeam, 1982; Wolpoff, 1982). In this analysis, the Euroafrican ramapithecines were studied because their geographical proximity to the earliest East African hominid localities made them more likely to include the ancestors of the 
first hominids than their Asian counterparts, which in any event appear to include the ancestors of Pongo and Gigantopithecus (Pilbeam, 1979, 1985; Andrews and Tekkaya, 1980; Wolpoff, 1982; Andrews, 1983; Ward and Kimbel, 1983; Shea, 1985). The comparative sample employed here included dental specimens preserving at least one complete lower first molar $(\mathrm{N}=23)$ from the Kenyan site of Fort Ternan, the Turkish sites of Pasalar, Çandir, and Mt. Sinap, the Hungarian locality of Rudabànya, and from Ravin de la Pluie, Greece. These sites were subdivided into an early group including Ft. Ternan, Pasalar, and Çandir, dating to approximately 15-14 Ma, and a later group including Mt. Sinap, Rudabànya, and Ravin de la Pluie, which dates to about 11-10 Ma (Szalay and Delson, 1979; de Bonis et al., 1981; Simons, 1981; Morbeck, 1983; Pilbeam, 1985). These subdivisions were created to facilitate the appreciation of the graphic comparisons presented in this investigation. Ramapithecine mandibular specimens that preserved at least part of the equivalent morphology found in KNM-LT $329(\mathrm{~N}=9)$ were taken from Rudabànya and Ravin de la Pluie.

A sample of modern chimpanzees was analyzed to address the second hypothesis, which stated that Lothagam was a representative of the African pongid clade. This modern sample was employed because there are, unfortunately, no fossil remains now known that can be attributed to the specific ancestors of the modern African apes. Chimpanzees were chosen for study rather than gorillas because of their approximate size similarity to Lothagam and because of their more generalized skeletal and dental form when compared to the gorilla. Eighty-three dental and 63 mandibular specimens from the Cleveland Museum of Natural History formed this chimpanzee sample.

Unlike earlier attempts to ascertain the evolutionary affinities of the Lothagam fossil, this study greatly benefits from the large sample of Australopithecus afarensis specimens now generally available for analysis (Johanson et al., 1982; White and Johanson, 1982). This bears directly on the testing of the "Lothagam as hominid" hypothesis. The most recent publications that addressed this issue (McHenry and Corruccini, 1980; Corruccini and McHenry, 1980) were able to include in their work only three $A$. afarensis specimens from Laetoli and none from Hadar. The $A$. afarensis sample analyzed in this study includes 22 dental specimens (six from Laetoli and 16 from Hadar) and 16 mandibular specimens (three from Laetoli and 13 from Hadar). Finally, since the first reports dealing with KNM-LT 329 mentioned its similarity to South African A. africanus (Patterson et al., 1970; Simons, 1978), a sample of these australopithecines, from Taung, Sterkfontein, and Makapansgat, was studied as well (dental, $\mathbf{N}=17$; mandibular, $\mathbf{N}=11$ ).

Dental and mandibular metrics were computed for each sample and compared to those taken on the original Lothagam specimen (by M.H. Wolpoff). The raw mesiodistal length and buccolingual breadth measurements on the chimpanzee dental sample and the dental/gnathic measurements on the original ramapithecine and $A$. africanus fossil material were also provided by Wolpoff. Mandibular metrics of the chimpanzee mandibles were taken by me from the collections at the Cleveland Museum of Natural History. Australopithecus afarensis metric data were taken from White $(1977 \mathrm{~b}, 1980)$, Johanson et al. (1982), White and Johanson (1982), as well as from Wolpoff's unpublished measurements. Morphological comparisons between the primary cast of Lothagam (provided to the University of Michigan by its discoverer, B. Patterson) and representatives of chimpanzee specimens, ramapithecines (primary casts), and australopithecines (primary casts) were also undertaken. A comprehensive list of the fossil specimens employed in this study may be found in Table 1.

\section{Description of KNM-LT 329}

White's published description (1977a; pp. 222-223) of the original mandibular corpus will be employed in association with my own observations made on the primary cast of KNM-LT 329 in this brief description of the specimen. An anatomical description of the $M_{1}$ will also be provided, since none has been published.

The specimen consists of a "fragment of adult right mandibular corpus including the crown of $M_{1}$ and broken roots of $M_{2}$ and $M_{3}$. The basal contour is intact from below the $M_{2}$ roots to about $10 \mathrm{~mm}$ behind the $\mathrm{M}_{3}$ level and the ends of the fragment have suffered jagged fractures" (White, 1977a, p. 222). There is an anteroposteriorly oriented crack running the length of the fragment on both the lateral and medial aspects. It is widest beneath the $M_{3}$ roots and thinnest beneath the $\mathbf{M}_{1}$. 
TABLE 1. List of the specimens employed in this study

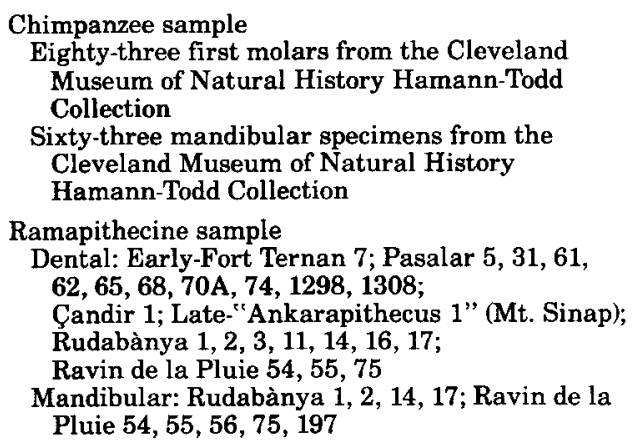

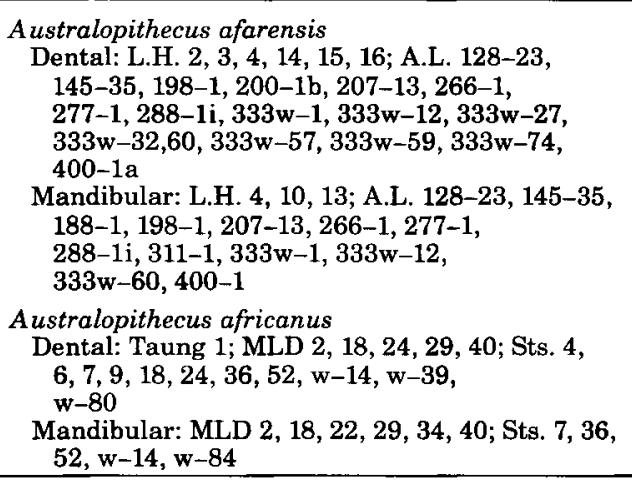

\section{Morphology of the corpus}

Lateral aspect: A weak lateral prominence marks the root of the ramus. "The root of the ramus is lateral to $\mathrm{M}_{3}$ and placed high on the corpus. The extramolar sulcus is shallow and narrow. ... The fragment essentially lacks a lateral superior torus but had a bulging alveolar portion" (White, 1977a, pp. 222223). An outswing of the lateral corpus anterior to the $\mathrm{M}_{1}$ may have led to a large canine socket, possibly conferring a $U$ shape to the dental arcade. The possibility that this outswing may have been the result of postmortem deformation, though, cannot be definitively ruled out (White, personal communication). The single mental foramen is an elongate oval, opening anterosuperiorly. It is located above midcorpus height at the $\mathrm{P}_{4} / \mathrm{M}_{1}$ position.

Medial aspect: "The medial corpus contours show a pronounced and extensive subalveolar fossa, occupying over $2 / 3$ of the corpus height below the $\mathrm{M}_{2}$ position" (White, $1977 a$, p. 223). There is very slight development of the inferior transverse torus immediately beneath the $\mathbf{M}_{1}$.

Basal aspect: The basal contour is thin and follows a slight S-shaped curve. It is thickest beneath $\mathbf{M}_{2} / \mathbf{M}_{3}$ and thinnest immediately posterior to $\mathrm{M}_{3}$.

\section{Morphology of the $\mathrm{M}_{1}$}

The occlusal outline is a rounded square. The tooth is very heavily worn, the metaconid remaining the highest cusp. There is continuous dentine exposure along the buccal cusps; a dentine crater measuring $3.2 \mathrm{~mm}$ buccolingually pits the protoconid. The hypoconid and hypoconulid form a continuous dentine crater that is deep and trapezoidally shaped. It measures $4.2 \mathrm{~mm}$ buccolingually by $5.6 \mathrm{~mm}$ mesiodistally. Neither metaconid nor entoconid are pitted. The large, concave, mesial interproximal wear facet measures 5.6 $\mathrm{mm}$ buccolingually; the distal interproximal wear facet is smaller, displaced lingually, flat, and measures $4.2 \mathrm{~mm}$ buccolingually. Both reach the occlusal rim.

The five major cusps from largest to smallest are protoconid=metaconid, hypoconid, entoconid, hypoconulid. The hypoconulid is very reduced and situated on the midline. The buccal face is strongly bilobed because of the strong convexity of the buccal cusp bases. The lingual face is more vertical. There is a well-marked, mesial buccal groove running from the occlusal edge to the enamel line; there is no lingual groove.

\section{RESULTS \\ Morphology}

The Lothagam specimen displays a mosaic of features some of which are shared with and others of which are dissimilar to the combined nonhominid sample. The shared features include the "pongid-like . . . flattened lateral corpus contours" and "the clear anterior opening of the single [mental] foramen" (White, 1977a, p. 308). The outswing lateral to the $M_{1}$ on the Lothagam mandible is greater than that seen in any hominid and may indicate that before broken the mandible had a very large canine and a pongidlike, U-shaped arcade. Moreover, KNM-LT 329 possesses a narrow and shallow extra- 
molar sulcus and a thin corpus base, features seen in Pan and the smaller ramapithecines. However, in chimpanzees (B-411, B-1738, B1768) approaching the corpus height of Lothagam, the extramolar sulcus is usually wider and deeper.

Differences noted between Lothagam and the nonhominid sample include a relatively anterior position for the origin of the ascending ramus (determined by which teeth are obscured by the ascending ramus when the mandible is viewed in proper lateral aspect, as in White [1977a]) and the wide alveolus (determined by the mininum distance between the buccal and lingual alveolar margins at $\mathbf{M}_{1}\left(\mathbf{M}_{2}\right)$ in Lothagam. In the chimpanzees and ramapithecines the ramus origin is generally centered about $\mathrm{M}_{3}$, while in the Lothagam mandible the ramus originates at $\mathbf{M}_{2} / \mathbf{M}_{3}$ (White, 1977a). Concerning the broad alveolus in KNM-LT 329, it is interesting to note that it is wider than that seen in even larger toothed ramapithecines such as RPL 75.

In features that depart from the nonhominid state described above, Lothagam approaches the condition observed in the australopithecines. The hominids and KNMLT 329 share the wide alveolus and relatively anterior position of the origin of the ascending ramus, around the $\mathrm{M}_{2} / \mathrm{M}_{3}$ position. Also, the vertical position of the mental foramen, above the midcorpus in KNM-LT 329 , is uncharacteristic of the ramapithecines and Pan, whose foramina are commonly closer to the base of the corpus. In $A$. afarensis, the mental foramen may be slightly above midcorpus (A.L. 333w-la, A.L. 145-35) at midcorpus (A.L. 400-1, A.L. 1881, A.L. 128-23) or below the midcorpus position (A.L. 266-1, A.L. 333w-12, A.L. 277-1), while in $A$. africanus it is uniformly above (White et al., 1981). However, this is not to say that Lothagam resembles both species equally; in fact, it shares much more in common with $A$. afarensis (contradicting Corruccini and McHenry, 1980). Though these shared characters are considered to be symplesiomorphic, it is important to note that these same primitive retentions, which led to the reluctance of White (1977a) and Howell (1978) to accept Lothagam as an australopithecine, are now seen as characteristic of the earliest hominid, A. afarensis. For example, the "pongid-like" anterior orientation of the mental foramen in KNM-LT 329 (White, 1977 a, p. 308) is now recognized to be char- acteristic of $A$. aforensis, as demonstrated in A.L. 145-35 and A.L. 333w-1a,1b (White et al., 1981; Kimbel et al., 1984). Also, the primitive nature of the subalveolar hollowing (White, 1977a) and thin mandibular corpus base can be found within the normal range of variation in $A$. afarensis. A series of Hadar mandibles that illustrate this range of subalveolar hollowing and thin base can be listed (from thinnest to thickest): A.L. 198-1, A.L. 333w-12, A.L. 188-1, A.L. 145-35, A.L. 333w1a, A.L. 333w-60. Of these specimens, A.L. 198-1 very closely resembles KNM-LT 329 . Their posterior cross sections are markedly similar, while their basal aspects are both quite thin, each displaying a pregonial concavity on the lingual aspect that imparts a slight S-shaped curve to the base. Other primitive features shared between Lothagam and $A$. afarensis include the flattened lateral corpus contours (White and Johanson, 1982) and narrow and shallow extramolar sulci (White et al., 1981).

Concerning virtually all of the above features, the $A$. africanus condition is derived (White et al., 1981; Wolpoff, 1983). These apomorphies (with respect to the ramapithecines, Pan, and A. afarensis, as well as Lothagam) include a mental foramen that opens laterally (MLD 18, 40; Sts. 7), a welldeveloped superior transverse torus (MLD 18, 40 ), a thick corpus base (MLD 40), a thickened lateral corpus (MLD 18, 40), and a broad and deep extramolar sulcus (MLD 40; Sts. 52b). Additionally, A. africanus is increasingly derived with respect to some hominid apomorphies noted in $A$. afarensis and in Lothagam. These features include a mental foramen placed well above midcorpus height, the absolutely large occlusal area of the $M_{1}$, an absolutely thicker and taller mandibular corpus, and a very reduced canine.

Morphological comparisons between the first molars of KNM-LT 329 and representatives from the other samples revealed a mixture of primitive and derived features in the Lothagam specimen. The Lothagam $\mathbf{M}_{1}$ is thickly enameled; there is extensive dentine exposure on the heavily worn buccal occlusal surface, and though there is appreciable wear on the lingual cusps, neither is perforated. Chimpanzee teeth are uniformly thinly enameled (Gantt, 1977, 1983), and all cusp tips perforate during the initial phases of wear. Ramapithecine and australopithecine dentitions are all thickly enameled (Simons and Pilbeam, 1972; Kay, 1981; Ward and Pil- 
beam, 1983). However, it is important to note Martin's work $(1983,1985)$ concerning hominoid dental enamel, which demonstrates that the "thick/thin" dichotomy is only partially informative with respect to evolutionary relationships. The speed at which the dental enamel prisms form during development is considered to be at least as phylogenetically important as gross thickness. Unfortunately, this evidence as it relates to Lothagam is unavailable since it requires sectioning of the tooth and since "studies . . . based on estimates on worn teeth or naturally fractured teeth, are of limited value" (Martin, 1985 , p. 260).

The wear slope displayed on the Lothagam $\mathrm{M}_{1}$ is shared by the chimpanzee, ramapithecine, and $A$. afarensis samples. This pattern of extreme buccal coupled with moderate to light lingual wear (Smith, 1984) is not seen in the majority of $A$. africanus specimens. Unlike Lothagam, which retains a high and well-delineated lingual profile, an $A$. africanus specimen with the same degree of buccal wear (MLD 40) is worn nearly flat on its lingual occlusal surface.

The reduction of the hypoconulid in the $\mathrm{M}_{1}$ of KNM-LT 329 is a feature shared only with the australopithecines. The ramapithecines and Pan both possess well-defined hypoconulids that confer a rounded, rectangular shape to their lower molars. The rounded square shape of the Australopithecus $\mathrm{M}_{1}$ is due in large part to the reduced hypoconulid, while interproximal attrition probably contributed to this condition as well.

Subocclusally, the Lothagam $\mathbf{M}_{1}$ shares a high root divergence (close to the crown of the tooth) with the ramapithecines and Australopithecus, while chimpanzee roots normally bifurcate more inferiorly with respect to the crown. As in A. afarensis, the Lothagam $\mathrm{M}_{2}$ displays a mesial root that is broader buccolingually than the distal root (Ward et al., 1982). This appears to be the case as well in $A$. africanus and the ramapithecines but not in Pan, whose roots are approximately equivalent in breadth.

\section{Metrics}

Minimum breadth and height measurements of the mandibular corpus at the $\mathrm{M}_{1}$ / $\mathrm{M}_{2}$ position were taken for every specimen in each sample. Sample means and ranges were recorded and compared with measurements derived from the Lothagam specimen. The corpus breadth of $19.5 \mathrm{~mm}$ for Lothagam exceeded not only all nine ramapithecines measured but also the entire sample of 63 chimpanzees. Conversely, only one of ten $A$. africanus specimens (MLD 34) were thicker at $\mathbf{M}_{1} / \mathbf{M}_{2}$ than KNM-LT 329. Lothagam most closely approximated the $A$. afarensis sample mean of $20.9 \mathrm{~mm}$, a figure less than $1.5 \mathrm{~mm}$ larger than the breadth of the Lothagam mandible (Fig. 1).

The minimum height at $\mathrm{M}_{1} / \mathrm{M}_{2}$ of KNM-LT 329 is distorted by a crack on its lingual surface, which measures $1.1 \mathrm{~mm}$ vertically, posteroinferior to the $M_{1}$. The height I have reported for Lothagam, $32.1 \mathrm{~mm}$, takes this crack into account. Seven ramapithecine specimens provided height measurements, three from Rudabànya and four from Ravin de la Pluie. Though none of the Hungarian specimens was as tall as Lothagam, three of the four mandibles from Ravin exceeded the Lothagam corpus height; in fact, two (RPL 56,75 ) were over $10 \mathrm{~mm}$ taller. When corpus height was compared to the australopithecines, KNM-LT 329 fell within the range of both species, though it was closer to the $A$. afarensis mean (about $.5 \mathrm{~mm}$ taller) and farther from $A$. africanus (over $1.5 \mathrm{~mm}$ shorter). Of the 63 chimpanzee mandibular corpus heights recorded, only two exceeded the height of Lothagam (Fig. 2).

When mandibular corpus breadth was divided by height, both australopithecine species demonstrated a tendency for increasing breadth relative to height; in $A$. afarensis the mean breadth/height quotient was .66, while in $A$. africanus it was .71 (Fig. 3). Conversely, both Pan and the ramapithecines displayed mandibular corpora that, on average, were half as thick as they were tall; both the ramapithecine and Pan means computed to .49 . Lothagam's quotient of .61 sorts most closely with the $A$. afarensis average, though it is not out of the ranges of the Pan and ramapithecine samples. Table 2 summarizes the results of the mandibular metric comparisons.

In the dental metrics, $\mathrm{M}_{1}$ occlusal area was estimated for each specimen by multiplying the length and breadth measurements of each tooth. An occlusal area of $163.8 \mathrm{~mm}^{2}$ was calculated for the Lothagam $\mathrm{M}_{1}$, a figure surpassing 22 of 24 ramapithecine $M_{1}$ areas, whose mean as a sample was $113.2 \mathrm{~mm}^{2}$ (Fig. 4). It is interesting to note, however, that relative to mandibular height ( $\mathbf{M}_{1}$ occlusal area as a percentage of mandibular height squared) the Lothagam $\mathbf{M}_{1}$ was larger than even the largest toothed ramapithecine, RPL 


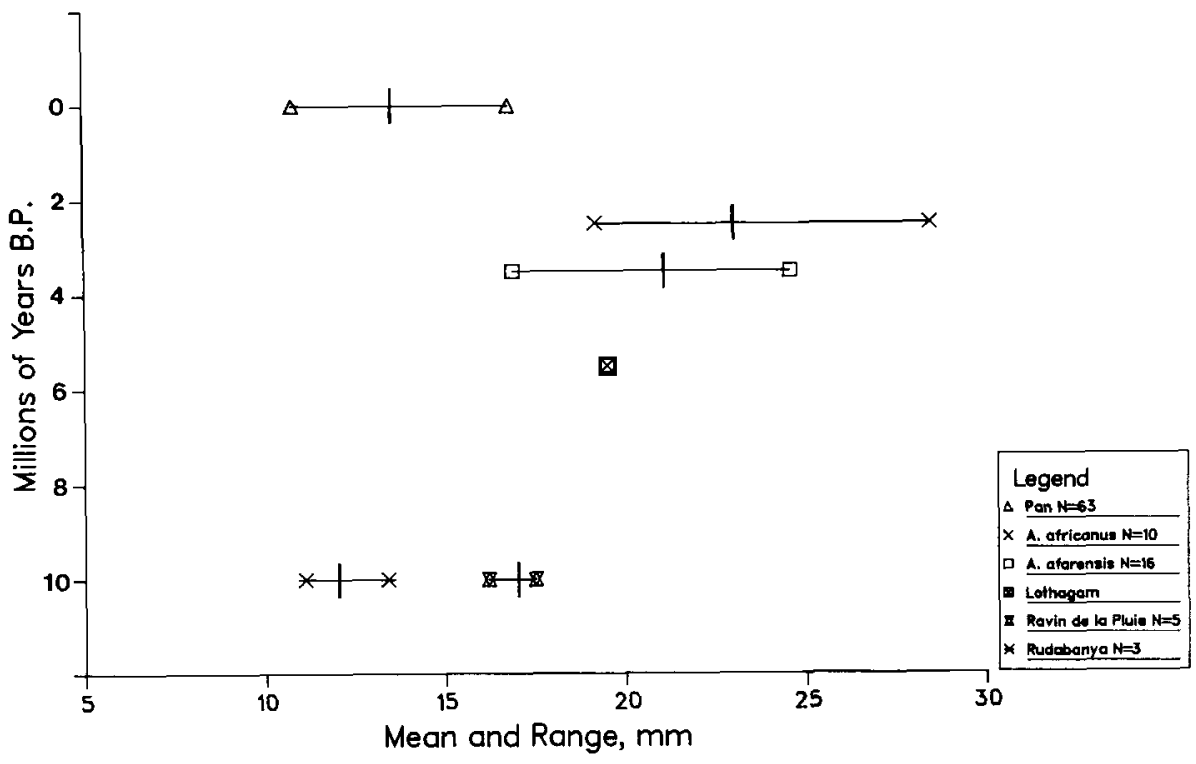

Fig. 1. The means and ranges of minimum mandibular corpus breadth, taken at $\mathbf{M}_{1} / \mathbf{M}_{2}$, are displayed for each sample and for Lothagam.

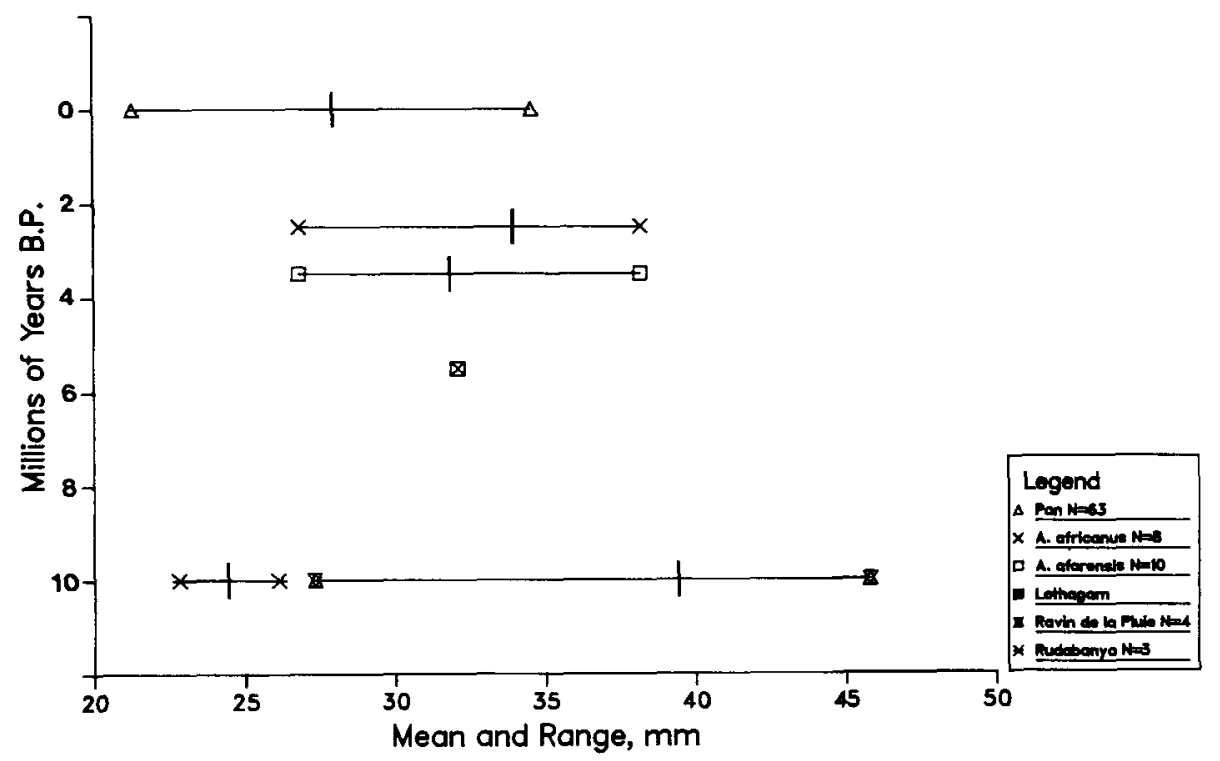

Fig. 2. The means and ranges of minimum mandibular corpus height, taken at $\mathbf{M}_{1} / \mathrm{M}_{2}$, are displayed for each sample and for Lothagam. 


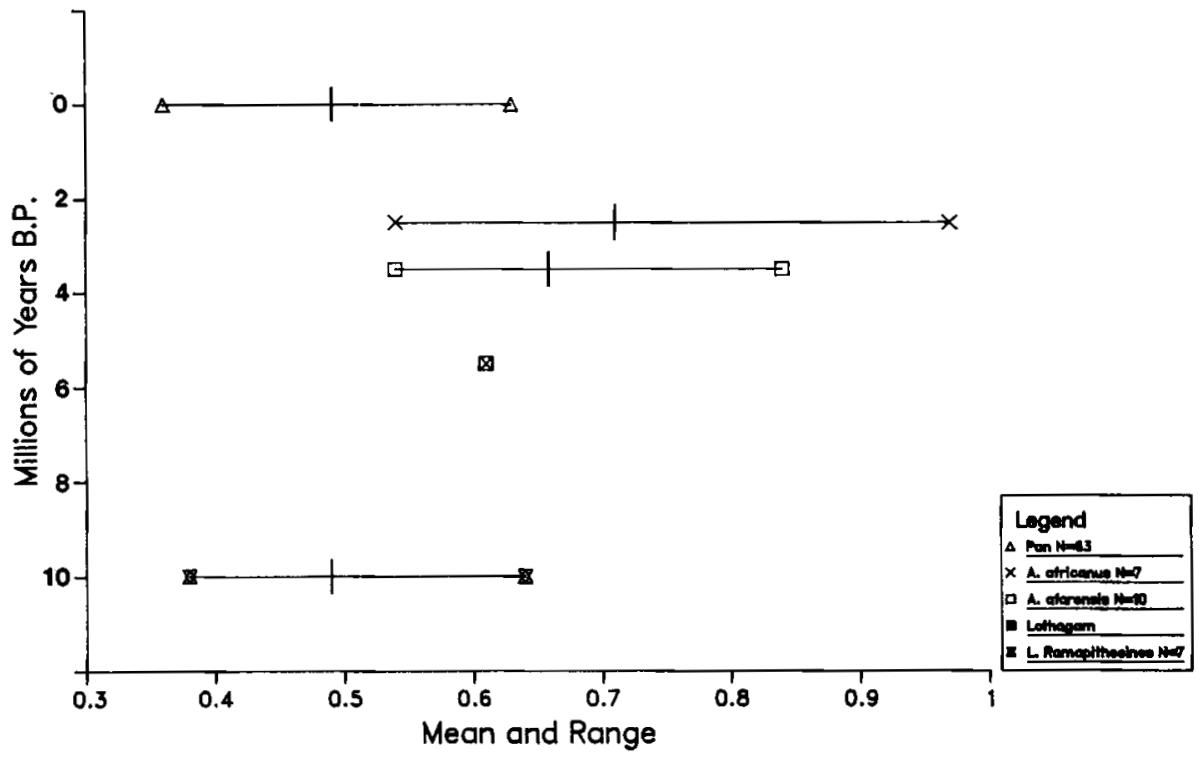

Fig. 3. The means and ranges of mandibular corpus breadth divided by height, taken at $\mathbf{M}_{1} / \mathbf{M}_{2}$, are displayed for each sample and for Lothagam. Only those specimens from which both a breadth and height were available were used in this measurement.

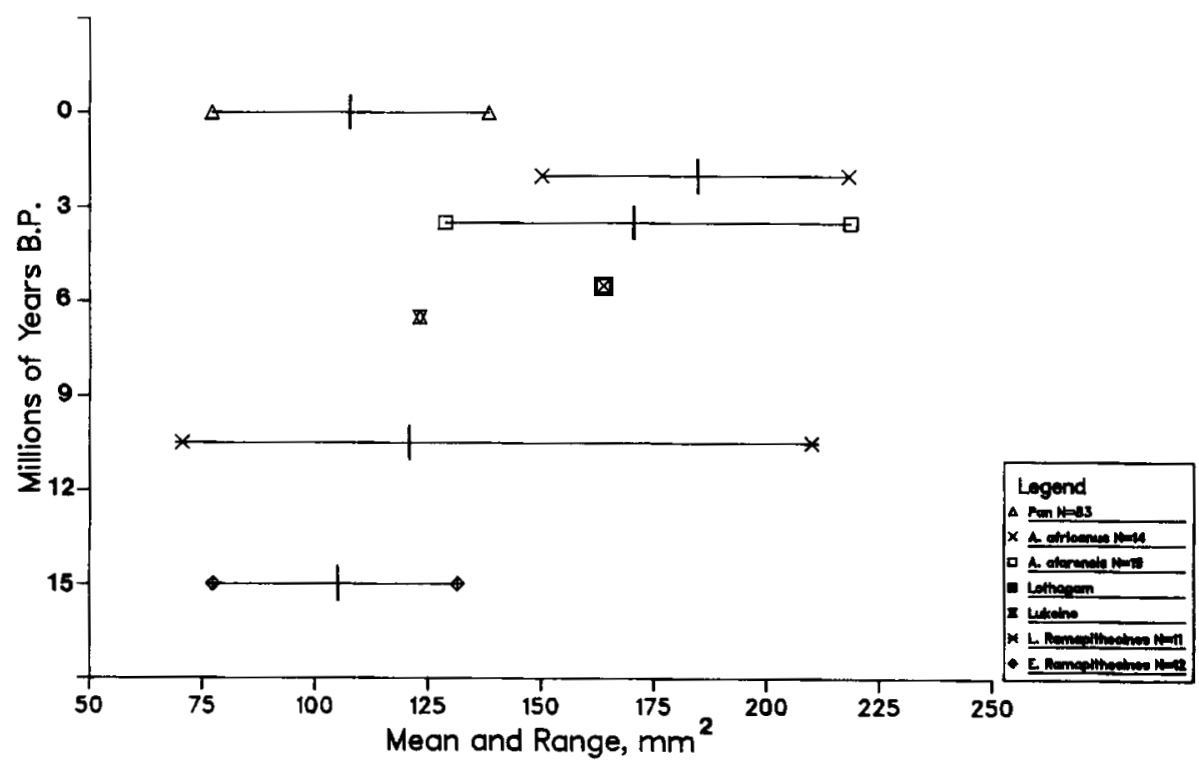

Fig. 4 The means and ranges of the length times the breadth of the $\mathbf{M}_{1}$ (estimated occlusal area) are displayed for each sample and for Lukeino and Lothagam. Only those specimens from which both an $M_{1}$ length and breadth were available were used in this measurement. 


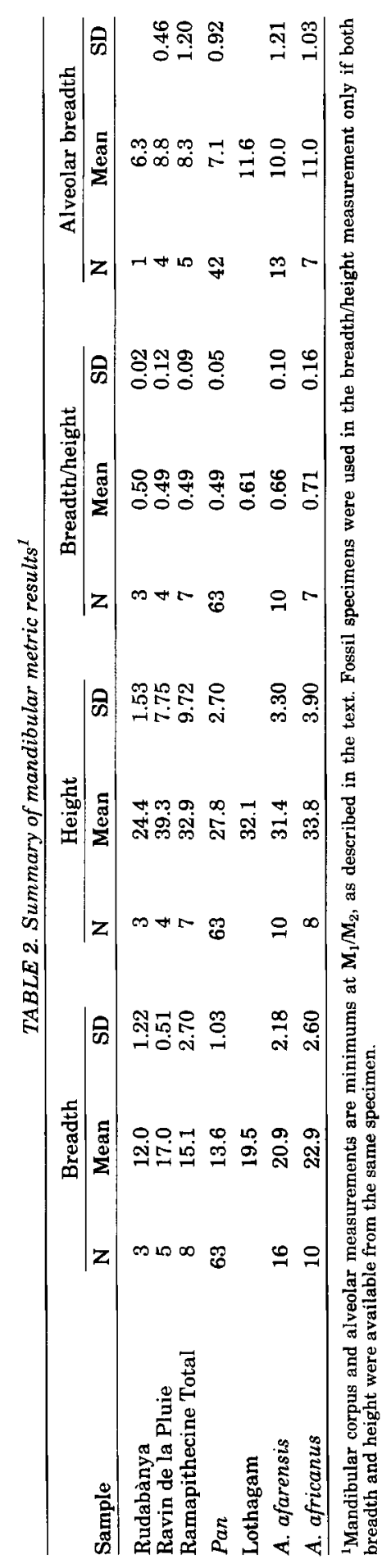


75 (.16 in KNM-LT 329, .12 in RPL 75). This ratio was used to demonstrate the relatively large size of the Lothagam $\mathrm{M}_{1}$ by holding mandibular corpus height constant.

In comparisons with the chimpanzee sample, Lothagam's occlusal area proved to be greater than all 83 of the ape molars. Though a similar relation holds for mandibular breadth, the difference in molar size is more dramatic, as illustrated by the following percentages; KNM-LT 329 was only $7 \%$ thicker than the thickest chimpanzee jaw, while its first molar was $16 \%$ larger than the largest chimpanzee $\mathrm{M}_{1}$.

Once again, KNM-LT 329 falls within the australopithecine range of variation regarding its $\mathrm{M}_{1}$ occlusal area, though it is markedly closer to the $A$. afarensis mean of $\mathbf{1 7 1 . 2}$ $\mathrm{mm}^{2}$. The A. africanus average of $184.1 \mathrm{~mm}^{2}$ is $20.3 \mathrm{~mm}^{2}$ larger than Lothagam and only four of $14 \mathrm{~A}$. africanus $M_{1}$ 's are smaller than Lothagam's.

An interesting feature shared between Lothagam and the australopithecines that bears on the taxonomic status of KNM-LT 329 is the relative equivalence of the length and breadth of the first molar (Fig. 5). The length/breadth ratio in Lothagam is .98 , the $A$. afarensis average is 1.01 , while the $A$. afarensis sample averages 1.02. Conversely, none of the 23 ramapithecine first molars are broader than they are long, and as a sample their length/breadth quotient is 1.09 . Of 83 chimpanzee $\mathrm{M}_{1}$ 's, 78 have lengths exceeding their breadth, and the chimpanzee sample mean in this measure is 1.11 . These ratios were very similar when age (as determined by occlusal wear on the $\mathrm{M}_{1}$ ) was held constant. Though interproximal attrition is known to shorten the mesiodistal length of molars, chimpanzees $(N=9)$ and specimens of $A$. afarensis $(\mathrm{N}=5)$ that exhibited occlusal wear similar to that of Lothagam fell extremely close to their whole sample means in the $M_{1}$ length/breadth quotient (1.10 and 1.02 , respectively). A summary of the results of the $\mathrm{M}_{1}$ metric comparisons is provided in Table 3.

\section{DISCUSSION}

The morphological and metric comparisons afford the opportunity to assess the evolutionary affinities of the Lothagam mandible within the framework of the three hypotheses: 1) Lothagam as predivergence, ancestral hominoid; 2) Lothagam as postdivergence, African protopongid; and 3) Lothagam as postdivergence, early hominid. All three hypotheses generally accept the same phylogeny for the origin of the hominid and

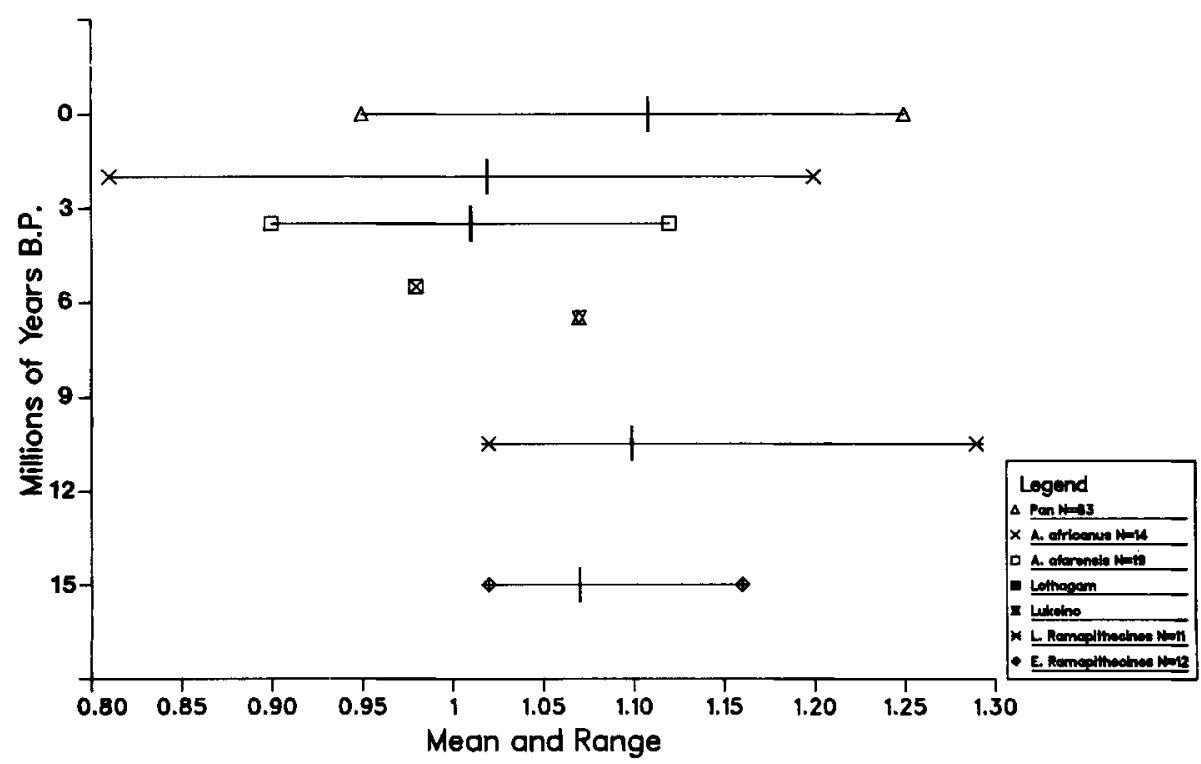

Fig. 5. The means and ranges of the length divided by the breadth of the $M_{1}$ are displayed for each sample and for Lukeino and Lothagam. Only those specimens from which both an $M_{1}$ length and breadth were available were used in this measurement. 


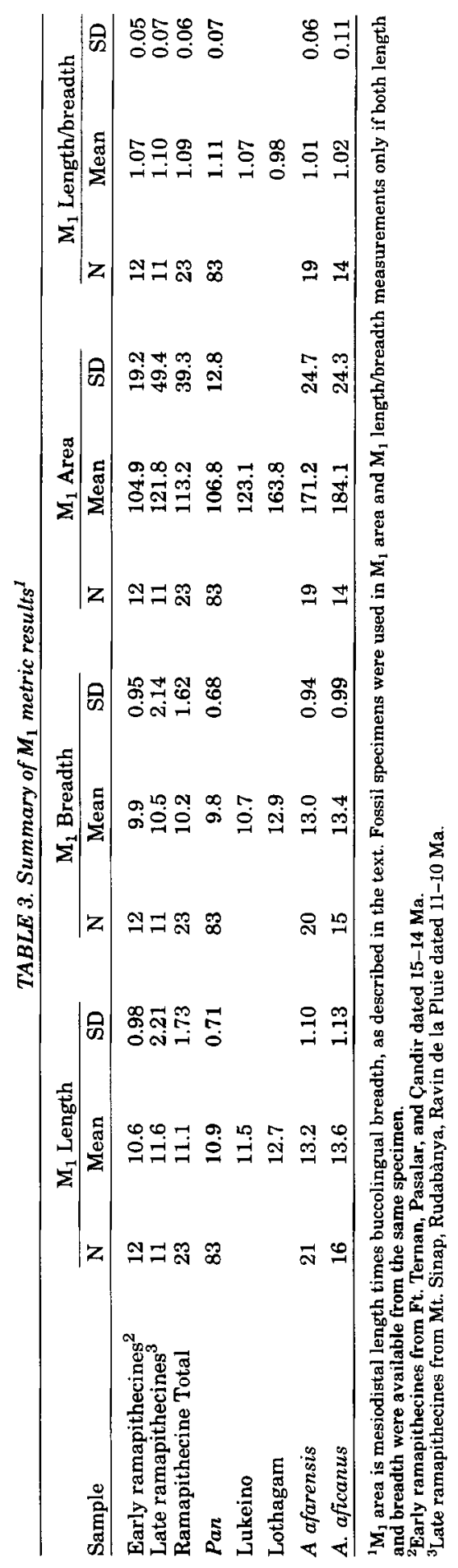




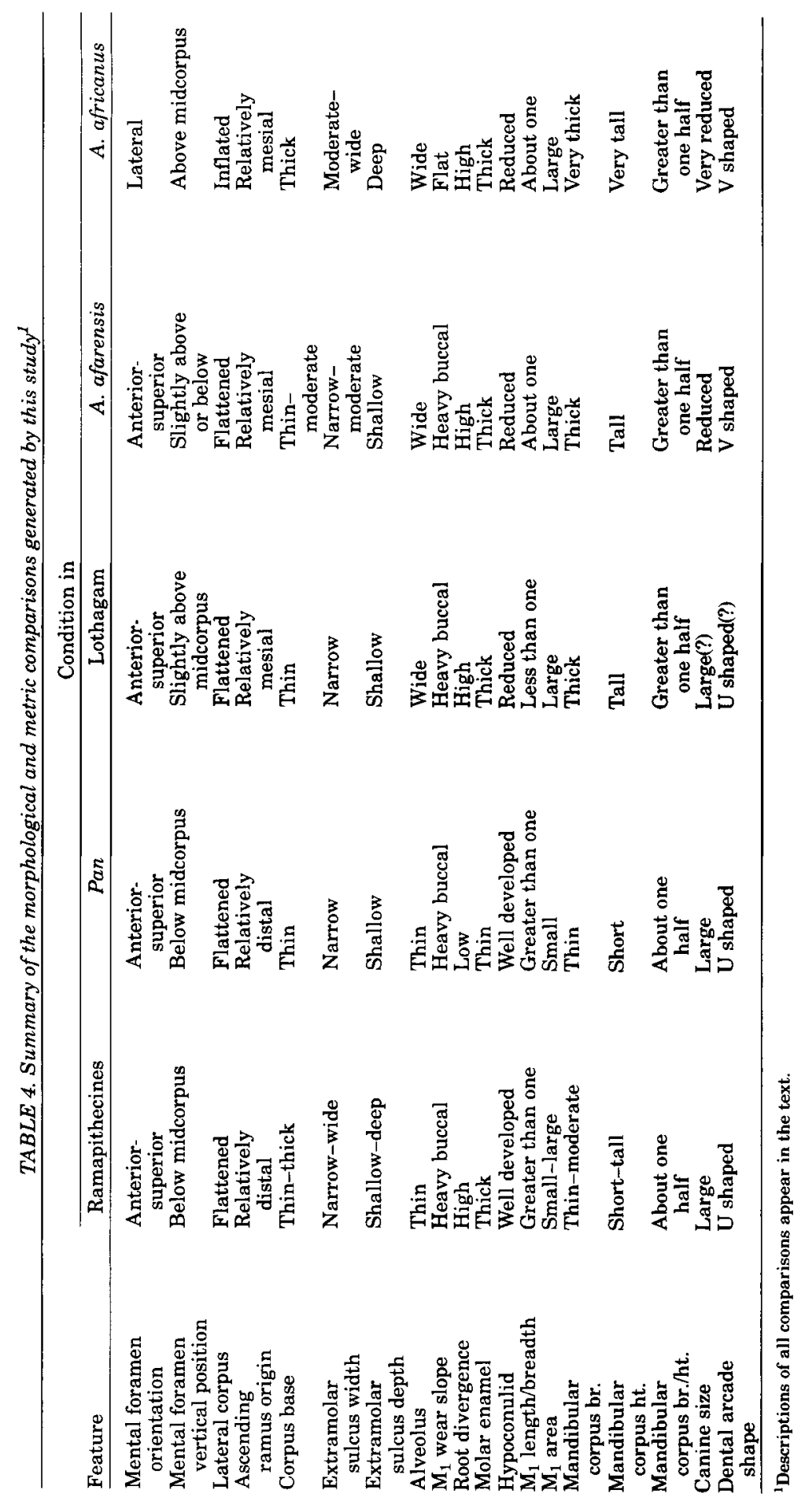


pongid clades, namely, that both were derived from ramapithecine stock in a cladogenetic event that occured between 14-5 Ma (Sarich and Wilson, 1967; Pilbeam, 1979, 1985; Greenfield, 1980, 1983; Szalay and Delson, 1979; Simons, 1981; Wolpoff, 1980, 1982; Kay and Simons, 1983; Ward and Kimbel, 1983; Gingerich, 1984). Therefore, the ramapithecine condition is generally agreed to be plesiomorphic for these three groups, while deviations from this state in the pongid and hominid lines are necessarily apomorphies.

Table 4 provides a summary of the morphological and metric comparisons presented in the following discussion. Many primitive retentions in KNM-LT 329 lend phenetic support to the first hypothesis, including anterior-superior mental foramen orientation, flattened lateral corpus contours, thick molar enamel, a well-marked buccolingual $\mathrm{M}_{1}$ wear gradient, the possibility of a large canine and a U-shaped dental arcade, and a high root divergence. However, Lothagam displays other decidedly derived morphological attributes. These include a relatively mesial ascending ramus origin, a wide alveolus, a mental foramen above midcorpus height, and a reduced hypoconulid. The metric results do not support the first hypothesis either, since Lothagam is thicker than all nine ramapithecine mandibular corpora. KNM-LT 329 also displayed a mandibular breadth/height ratio that exceeded seven of eight ramapithecine values. Dental metrics show that the Lothagam $\mathbf{M}_{1}$ has an absolutely larger occlusal area than 22 of 24 ramapithecine $\mathbf{M}_{1}$ 's and a relatively larger area (when compared to mandibular height) than the two absolutely larger ramapithecine first molars. Also, the $\mathrm{M}_{1}$ of KNM-LT 329 is broader than long, a condition not seen in any of the ramapithecine $M_{1}$ 's. Thus, the first hypothesis does not seem to be the best fit to the data.

Similar findings are suggested when the second hypothesis is evaluated, though Lothagam in fact shares less with the chimpanzees than it did with the ramapithecines. This runs counter to the conclusions offered by Corruccini and McHenry, who stated that "it is phenetically much easier to derive the mandibular fossils from Lukeino, Lothagam, and Laetolil from a Pan-like predecessor than from Sivapithecus or Ramapithecus" (1980, p. 219). For example, Pan has a relatively wide extramolar sulcus for its mandibular corpus height, reduced cheek tooth enamel thickness, and a relatively low molar root divergence. Lothagam diverges morphologically from the chimpanzee samples in all of the features that were previously listed for the ramapithecine comparisons. The metric differences, however, were even more dramatic, since only two of 63 chimpanzee mandibles were as tall, while none of the mandibles were as thick as Lothagam. Additionally, none of the $83 \mathrm{M}_{1}$ 's were as large as the $M_{1}$ of KNM-LT 329, while only five of 83 chimpanzee $M_{1}$ 's had buccolingual dimensions that exceeded their mesiodistal measurements.

Interestingly, although Lothagam certainly does not seem to fit this hypothesis, the other hominid fossil from this time range, the Lukeino molar, may represent a post divergence, African protopongid. Evidence supporting this notion includes its relatively small molar occlusal area, which falls within the Pan range, while being smaller than all of the $A$. afarensis $\mathrm{M}_{1}$ 's. Lukeino's length/ breadth quotient of the $M_{1}$ is 1.07 , and there is strong development of the hypoconulid, both of which are Pan-like features. It is unlikely that both the Lukeino and Lothagam individuals belonged to populations that were ancestral to the hominids, since there is a great size discrepancy in $\mathrm{M}_{1}$ occlusal area between the two $\left(123.1 \mathrm{~mm}^{2}\right.$ in KNM-LN $335,163.8 \mathrm{~mm}^{2}$ in KNM-LT 329; see Fig. 4, Table 3). Employing an $A$. afarensis sample variance, KNM-LT 329 and KNM-LN 335 are slightly less than two standard deviations away from each other, but if a Pan sample variance is used instead, the Lukeino molar is almost three standard deviations smaller than Lothagam. However, since the Lukeino $\mathrm{M}_{1}$ is only four square millimeters smaller than the smallest $A$. afarensis specimen (A.L. 288-1), membership in an ancestral hominid population cannot be conclusively ruled out.

The "Lothagam as hominid" hypothesis decidedly receives the most support from the results generated by this study (for an alternative view, see White, 1986). The apomorphies that are shared between Lothagam and the genus Australopithecus are the same features that distinguished KNM-LT 329 from the ramapithecines and Pan. These decisive, derived features are a relatively mesial ascending ramus origin, a wide alveolus, a mental foramen above midcorpus height, a very reduced hypoconulid, an absolutely 
thick mandibular corpus, a mandibular corpus breadth approaching its height, an absolutely and relatively large occlusal area of the $\mathrm{M}_{1}$, and an approximately equivalent length and breadth of the first molar.

\section{CONCLUSION}

It is hoped that the foregoing discussion has at least demonstrated the likelihood of hominid status for the Lothagam mandible. Contradicting Leakey (1973), KNM-LT 329 cannot be classed as a ramapithecine, since it displays the numerous hominid apomorphies enumerated above (see Table 4). There is even less support for the view that Lothagam is representative of an ancestral population on the African ape clade. In addition to the apomorphies shared between the hominids and Lothagam, Pan is derived away from the ramapithecines, hominids, and Lothagam in its relative extramolar sulcus breadth, thin molar enamel, and low root divergence. Interestingly, in 12 of Eckhardts' 16 repeatable measurements taken on chimpanzees and gorillas (1977), Lothagam falls roughly between both ranges of the extant hominoids. His contention that the "Lothagam mandible resembles modern African pongids" (Eckhardt, 1977, p. 356) would be supported if KNM.LT 329 consistently fell within the range of one or the other great apes, but as his results stand, Lothagam can only be interpreted as metrically occupying an intermediate position between Pan and Gorilla, a position similar to that occupied by the earliest hominids and their immediate forebears.

If Lothagam is to be accepted as hominid, the question remains: To which hominid species should it be assigned? In deference to the original researchers who assigned KNM-LT 329 to $A$. africanus (Patterson et al., 1970; Simons, 1978; Tobias, 1978) it should be noted that this species of Australopithecus was the most primitive that was adequately described in the literature at that time. However, present evidence indicates that $A$. africanus is clearly derived away from the condition of Lothagam and $A$. afarensis in its mental foramen orientation, extramolar sulcus width, mandibular base thickness, lateral corpus contours, and molar wear pattern. In addition, $A$. africanus is increasingly derived regarding hominid trends initiated in A. afarensis and Lothagam in such features as the mental foramen placement, the occlusal area of the $M_{1}$, the dimensions of the mandibular corpus, and the extreme reduction of the canine.

The majority of researchers who have studied the Lothagam mandible have appreciated its hominid affinities (Patterson et al., 1970; Howell, 1978; Simons, 1978, 1981; Tobias, 1978; Szalay and Delson, 1979; McHenry and Corruccini, 1980; Corruccini and McHenry, 1980; Tanner, 1981), but none had the opportunity to compare this fossil with an extensive sample of $A$. afarensis material. As can be appreciated from Table 4, KNMLT 329 and $A$. afarensis exhibit nearly identical morphostates in all but two of the 19 comparisons. Lothagam and $A$. afarensis are derived with respect to the ramapithecines and Pan in their mental foramen vertical position, ascending ramus origin, alveolar breadth, reduced hypoconulid and $\mathrm{M}_{1}$ length/ breadth quotient, mandibular dimensions, and first molar dimensions. Australopithecus afarensis and Lothagam are symplesiomorphic with respect to $A$. africanus in the features listed in the previous paragraph.

The two morphological comparisons that differ between Lothagam and $A$. afarensis concern Lothagam's putative lateral corpus outswing anterior to the $M_{1}$. This may have led, first, to quite a large canine and may have conferred, second, a pongid-like U shape to the dental arcade. An outswing of this magnitude is not observed in any of the $A$. afarensis mandibles preserving the equivalent region. Though this may in fact be a significant difference between Lothagam and the first unequivocal hominids, it is not a surprising feature from a fossil that is nearly 2 million years older than the earliest $A$. afarensis dental/gnathic material. Australopithecus afarensis canines are primitive with respect to later hominids in that they project beyond the tooth row and wear similarly to pongids (Johanson and White, 1979; White et al., 1981). It seems reasonable to assume, therefore, that Lothagam's canines were functionally similar, though possibly larger, than those of the later A. afarensis populations. If Lothagam's canines were in fact larger than $A$. afarensis, this would once again illustrate the mosaic nature of hominid evolution, since it is clear that the molar and posterior portion of the mandible preserved in KNM-LT 329 is very similar to that seen in $A$. afarensis. Contradicting Jolly (1970), the presence of a large canine in association with an expanded $\mathbf{M}_{1}$ occlusal area in Lothagam demonstrates that selection for 
larger molars was not necessarily concomitant with a reduction in canine size (Kay, 1981). This combination of features present in KNM-LT 329 indicates that increase in molar size occurred early on in the course of hominid evolution, while canine reduction proceeded at a less rapid pace. This evidence supports a gradualistic transformation of the earliest hominid masticatory apparatus.

Despite its early date and the possiblity that it possessed a large canine and U-shaped arcade, the abundant hominid apomorphies displayed in KNM-LT 329 supports the provisional placement of the Lothagam mandible into the taxon Australopithecus sp. cf. A. afarensis, thereby conferring upon it the title of earliest australopithecine known to date.

The appreciation of Lothagam as an australopithecine is informative with respect to which dental/gnathic features can be diagnostic in determining the evolutionary affinities of hominoid fossils derived from the Mio/ Pliocene. Postdivergence representatives of the pongid clade will be expected to display reduced, slowly forming cheek tooth enamel (Martin, 1983, 1985), a feature present in extant African apes that allows for the efficient microshearing of forest fruits and leaf (Kay, 1977, 1981; Scheine and Kay, 1977). Perhaps $X$ rays should be taken, or microsectioning performed, on unworn dental remains from this time range (such as Lukeino) in an attempt to determine enamel thickness and speed of formation (Martin, 1985). Also, a lowering of the root divergence of the molars would be expected, since this is the condition in Pan. The presence of a large canine, though, would probably not be diagnostic of either clade, since the purported large canine of the Lothagam mandible indicates that appreciable molar size increase began before significant canine reduction occurred.

Conversely, the apomorphies shared by Lothagam and the australopithecines reflect the hominization of the ancestral hominoid dental/gnathic complex. The hominids accentuated the trends initiated earlier by the ramapithecines in the Miocene (Wolpoff, 1982), which allowed for the exploitation of a wider range of foodstuffs including the hard package items available on the savannah (Jolly, 1970). This resulted in an even more powerful dental/gnathic complex, as indicated by the morphology already present in the Lothagam specimen. For example, the great absolute breadth of the mandibular corpus in conjunction with the width of the alveolus indicates larger, stouter, perhaps more divergent molar roots, which could have anchored the highly stressed cheek teeth more securely in the jaw. The relatively mesial ascending ramus origin may have conferred a mechanical advantage that allowed for the generation of more powerful masticatory forces in Lothagam and the early hominids. Also, the relatively and absolutely large $\mathbf{M}_{1}$ in Lothagam was a harbinger of the australopithecine trend of increasing molar size, which occurred over the following 4 million years.

Features such as these can be used to help distinguish the hominid from the nonhominid material in future Mio/Pliocene paleontological discoveries.

\section{ACKNOWLEDGMENTS}

Thanks to Milford Wolpoff for providing access to his original measurements and to the cast collections at the University of Michigan. Thanks to Bill Kimbel for allowing me to study and measure the chimpanzee material and the $A$. afarensis primary casts at the Cleveland Museum of Natural History. Thanks to R.E.F. Leakey for his correspondence concerning the status of the Lothagam specimen. Thanks to M.H. Wolpoff, W.H. Kimbel, R.E.F. Leakey, C.L. Brace, P.D. Gingerich, A. Walker, T.D. White, V.J. Vitzthum, and K. Hunt for discussion and to T.D. White for a preprint of his paper on the Lothagam fossil.

\section{LITERATURE CITED}

Andrews, P (1982) Hominoid evolution. Nature 295:185186.

Andrews, P (1983) The natural history of Sivapithecus. In RL Ciochon and RS Corruccini (eds): New Interpretations of Ape and Human Ancestry. New York: Plenum Press, pp. 441-464.

Andrews, P, and Tekkaya, I (1980) A revision of the Turkish Miocene hominoid Sivapithecus meteai. Paleontology 23:85-95.

Behrensmeyer, AK (1976) Lothagam, Kanapoi and Ekora: A general summary of stratigraphy and fauna. In Y Coppens, FC Howell, GLI Isaac, and RE Leakey (eds): Earliest Man and Environments in the Lake Rudolf Basin. Chicago: University of Chicago Press, pp. 163-172.

Brown, FH, McDougall, I, Davies, T, and Maier, R (1985) An integrated Plio-Pleistocene chronology for the Turkana basin. In E Delson (ed): Ancestors: The Hard Evidence. New York: Alan R. Liss, Inc., pp. 82-90.

Coppens, Y (1978) Le Lothagamien et el Shungurien, étages continentaux du Pliocène E. Afr. Bull. Soc. Geol. Fr. 20:39-44.

Corruccini, RS, and McHenry, HM (1980) Cladometric analysis of Pliocene hominids. J. Hum. Evol. 9:209221. 
Cronin, JE (1983) Apes, humans and molecular clocks: A reappraisal. In $\mathrm{RL}$ Ciochon and RS Corruccini (eds): New Interpretations of Ape and Human Ancestry. New York: Plenum Press, pp. 115-136.

de Bonis, L, Johanson, D, Melentis, J, and White, T (1981) Variations métriques de la denture chez les Hominoides primitifs: Comparaison entre Australopithecus afarensis et Ouranopithecus macedonesis. C.R. Acad. Sci. Paris 292:373-376.

Eckhardt, RB (1977) Hominid origins: The Lothagam problem. Curr. Anthropol. 18:356.

Feldesman, MR (1982) Morphometric analysis of the distal humerus of some Cenozoic catarrhines: The late divergence hypothesis revisited. Am. J. Phys. Anthropol. 59:73-95.

Gantt, DG (1977) Enamel of Primate Teeth. Ph.D. Thesis, Washington Unversity, St. Louis.

Gantt, DG (1983) The enamel of Neogene hominoids: Structural and phyletic implications. In RL Ciochon and RS Corruccini (eds): New Interpretations of Ape and Human Ancestry. New York: Plenum Press, pp. 249-298.

Gingerich, PD (1984) Primate evolution: Evidence from the fossil record, comparative morphology, and molecular biology. Yearbk. Phys. Anthropol. 27:57-72.

Goodman, M, Braunitzer, G, Stangl, A, and Shrank, B (1983) Evidence of human origins from haemoglobins of African apes. Nature 303:546-548.

Greenfield, LO (1980) A late divergence hypothesis. Am. J. Phys. Anthropol. 52:351-365.

Greenfield, LO (1983) Toward the resolution of discrepancies between phenetic and paleontological data bearing on the question of human origins. In RL Ciochon and RS Corruccini (eds): New Interpretations of Ape and Human Ancestry. New York: Plenum Press, pp. 695-704.

Howell, FC (1978) Hominidae. In VJ Maglio and HBS Cooke (eds): Evolution of African Mammals. Cambridge, MA: Harvard University Press, pp. 154-248.

Johanson, DC, and White, TD (1979) A systematic assessment of early African hominids. Science 203:321330.

Johanson, DC, White, TD, and Coppens, Y (1982) Dental remains from the Hadar Formation, Ethiopia: 19741977 Collections. Am. J. Phys. Anthropol. 57:454-603.

Jolly, C (1970) The seed-eaters: A new model of hominid differentiation based on a baboon analogy. Man 5:526.

Kay, RF (1977) Diets of early Miocene African hominoids. Nature 268:628-630.

Kay, RF (1981) The nut-crackers-A new theory of the adaptation of the Ramapithecinae. Am. J. Phys. Anthropol. 55:141-151.

Kay, RF, and Simons, EL (1983) A reassessment of the relationship between later Miocene and subsequent Hominoidea. In RL Ciochon and RS Corruccini (eds): New Interpretations of Ape and Human Ancestry. New York: Plenum Press, pp. 577-624.

Kimbel, WH, White TD, and Johanson, DC (1984) Cranial morphology of Australopithecus afarensis: A comparative study based on a composite reconstruction of the adult skull. Am. J. Phys. Anthropol. 64:337-388.

King, MC, and Wilson, AC (1975) Evolution at two levels in humans and chimpanzees. Science 188:107-116.

Leakey, REF (1973) Further evidence of Lower Pleistocene hominids from East Rudolf, North Kenya, 1972. Nature 242:170-173.
Lipson, S, and Pilbeam, D (1982) Ramapithecus and hominoid evolution. J. Hum. Evol. 11:545-548.

Martin, LB (1983) The Relationships of the Later Miocene Hominoidea. Ph.D. Thesis, University College, London.

Martin, L (1985) Significance of enamel thickness in hominoid evolution. Nature 314:260-263.

McHenry, HM, and Corruccini, RS (1980) Late Tertiary hominoids and human origins. Nature 285:397-398.

Morbeck, ME (1983) Miocene hominoid discoveries from Rudabànya: Implications from the postcranial skeleton. In RL Ciochon and RS Corruccini (eds): New Interpretations of Ape and Human Ancestry. New York: Plenum Press, pp. 369-404.

Patterson, B, Behrensmeyer, AK, and Sill, WD (1970) Geology of a new Pliocene locality in northwestern Kenya. Nature 226:918-921.

Pickford, M (1975) The Miocene sediments and fossils from the northern Kenya rift valley. Nature 256:279284.

Pilbeam, D (1979) Recent finds and interpretations of Miocene hominoids. Annu. Rev. Anthropol. 8:333-352.

Pilbeam, D (1985) Patterns of hominoid evolution. In E Delson (ed): Ancestors: The Hard Evidence. New York: Alan R. Liss, Inc., pp. 51-59.

Sarich, VM (1968) The origin of the hominids: An immunological approach. In SL Washburn and PC Jay (eds): Perspectives on Human Evolution. New York: Holt, Rinehart and Winston, pp. 94-121.

Sarich, VM (1970) Primate systematics with special reference to the Old World monkeys: A protein perspective. In JR Napier and PH Napier (eds): Old World Monkeys. New York: Academic Press, pp. 175-226.

Sarich, VM, and Cronin, JE (1976) Molecular systematics of the primates. In M Goodman and RE Tashian (eds): Molecular Anthropology. New York: Plenum Press, pp. 141-170.

Sarich, VM, and Wilson AC (1967) An immunological timescale for hominid evolution. Science 158:12001203.

Scheine, WS, and Kay, RF (1977) An analysis of chewed food particle size and its relationship to molar structure in the primates Cheirogaleus medius and Galago senegalensis and the insectivoran Tupaia glis. Am. J. Phys. Anthropol. 47:15-20.

Shea, BT (1985) On aspects of skull form in African apes and orangutans, with implications for hominoid evolution. Am. J. Phys. Anthropol. 68:329-342.

Sibley, CG, and Ahlquist, JE (1984) The phylogeny of the hominoid primates, as indicated by DNA-DNA hybridization. J. Mol. Evol. 20:2-15.

Simons, EL (1978) Diversity among the early hominids: A vertebrate paleontologist's viewpoint. In CJ Jolly (ed): Early Hominids of Africa. London: Duckworth, pp. 543-566.

Simons, EL (1981) Man's immediate forerunners. Phil. Trans. R. Soc. Lond. 292:21-41.

Simons, EL, and Pilbeam, D (1972) Hominoid paleoprimatology. In $\mathrm{R}$ Tuttle (ed): The Functional and Evolutionary Biology of Primates. Chicago: Aldine, pp. 3662

Smart, C (1976) The Lothagam I fauna: Its phylogenetic, ecological and biogeographic significance. In Y Cop pens, FC Howell, GLl Isaac, and RE Leakey (eds): Earliest Man and Environments in the Lake Rudolf Basin. Chicago: University of Chicago Press, pp. 361369. 
Smith, BH (1984) Patterns of molar wear in huntergatherers and agriculturists. Am. J. Phys. Anthropol. 63:39-56.

Szalay, FS, and Delson, E (1979) Evolutionary History of the Primates. New York: Academic Press.

Tanner, NM (1981) On Becoming Human. Cambridge University Press.

Tobias, PV (1978) The South African australopithecines in time and hominid phylogeny, with special reference to the dating and affinities of the Taung skull. In CJ Jolly (ed): Early Hominids of Africa. London: Duckworth, pp. 45-84.

Ward, SC, Johanson, DC, and Coppens, Y (1982) Subocclusal morphology and alveolar process relationships of hominid gnathic elements from the Hadar Forma. tion: 1974-1977 Collections. Am. J. Phys. Anthropol. $57: 605-630$

Ward, SC, and Kimbel, WH (1983) Subnasal alveolar morphology and the systematic position of Sivapithecus. Am. J. Phys. Anthropol. 61:157-171.

Ward, SC, and Pilbeam, DR (1983) Maxillofacial morphology of Miocene hominoids from Africa and IndoPakistan. In RL Ciochon and RS Corruccini (eds): New Interpretations of Ape and Human Ancestry. New York: Plenum Press, pp. 211-238.

Washburn, SL (1950) An analysis of primate evolution with particular reference to the origin of man. Cold
Spring Harbor Symp. Quant. Biol. 15:67-77.

Washburn, SL, and Moore, R (1974) Ape into Man. A Study of Human Evolution. Boston: Little, Brown.

White, TD (1977a) The Anterior Mandibular Corpus of Early African Hominidae: The Functional Significance of Shape and Size. Ph.D. Thesis, University of Michigan, Ann Arbor.

White, TD (1977b) New fossil hominids from Laetoli, Tanzania. Am. J. Phys. Anthropol. 46:197-230.

White, TD (1980) Additional fossil hominids from Laetoli, Tanzania: 1976-1979 specimens. Am. J. Phys. Anthropol. 53:487-504.

White, TD (1986) Australopithecus afarensis and the Lothagam mandible. (In press.)

White, TD, and Johanson, DC (1982) Pliocene hominid mandibles from the Hadar Formation, Ethiopia: 19741977 collections. Am. J. Phys. Anthropol. 57:501-544.

White, TD, Johanson, DC, and Kimbel, WH (1981) Australopithecus africanus: Its phyletic position reconsidered. S. Afr. J. Sci. 77:445-470.

Wolpoff, MH (1980) Paleoanthropology. New York: Knopf. Wolpoff, MH (1982) Ramapithecus and hominid origins. Curr. Anthropol. 23:501-522.

Wolpoff, MH (1983) Australopithecines: The unwanted ancestors. In $\mathrm{K}$ Reichs (ed): Hominid Origins. Washington DC: University Press, pp 109-126. 